\title{
Influence of hydraulic and organic load on the anaerobic-aerobic dairy wastewater treatment characteristics
}

\author{
Rustem Khabibullin ${ }^{1, *}$, Thao Le Huong ${ }^{1,2}$, and Andrey Petrov ${ }^{3}$ \\ ${ }^{1}$ Kazan National Research Technological University, K. Marks St. 68, Kazan, 420015, Russian Federation \\ ${ }^{2}$ Viet Tri University of Industry, Tien Kien, Lam Thao, Phu Tho, Viet Nam \\ ${ }^{3}$ Research Institute for Problems of Ecology and Mineral Wealth Use of Tatarstan Academy of Sciences, Daurskaya St. 28, Kazan, \\ 420087, Russian Federation
}

\begin{abstract}
The performance of the anaerobic-aerobic sequencing lab- scale reactors for the treatment of a milk processing wastewater was studied. The wastewater flow rate was varied from 78.0 to $149.0 \mathrm{ml} \bullet \mathrm{h}-1$ and organic matter content from 3.8 to $6.8 \mathrm{~g} \mathrm{COD} \cdot \mathrm{dm}^{-3}$. This corresponded to the change of dilution rate from 0.4 to $0.8 \mathrm{day}^{-1}$ and organic loading rate from 1.4 to $2.8 \mathrm{~g} \mathrm{COD} \cdot \mathrm{dm}^{-3} \cdot \mathrm{day}^{-1}$. An increase of hydraulic load reduced the treatment efficiency at the first anaerobic stage from 44.4 to $29.7 \%$, but it was compensated at the aerobic treatment stage. Increasing the organic loading rate improved the treatment efficiency at the anaerobic stage from 44.4 to $54.2 \%$. It was shown that spatial separation of anaerobic stage onto two phases increases the treatment efficiency in anaerobic stage and in whole (85.8 and 98.7\%) in comparison to non-separation mode ( 45.5 and $73.9 \%$, respectively). The correlation analysis of the organic loading rate $\mathrm{L}$, organic consumption rate $\mathrm{P}$ and dilution rate $\mathrm{D}$ on the treatment efficiency $\mathrm{E}$ allowed to obtain the equations can be used for mathematical optimization of the process.
\end{abstract}

\section{Introduction}

In developing countries milk production is growing at about $2.8 \%$ per year. In 2017,170 billion $\mathrm{kg}$ of milk was produced in Europe, $93 \%$ of it was processed into dairy products, including cheese $(37 \%)$, butter $(30 \%)$, cream $(13 \%)$, fresh milk $(11 \%)$, acidified milk $(4 \%)$, milk powder $(2 \%)$. Unfortunately, about $50 \%$ of the produced acid whey is untreated before disposal [1]. It is also known that dairy wastewater has high biological and chemical oxygen demand due to the high content of proteins, fats, lactose, as well as detergents and disinfectants. Without a properly organized treatment such wastewater can cause serious environmental problems $[2,3]$. Thus, there is an urgent need to develop new effective technologies of dairy plants wastewater treatment and to perform optimization and intensification of existing one [4].

Due to the high organic content, its high biodegradability, ability to solve environmental problems and obtain alternative energy anaerobic processes are known as more preferable methods of dairy wastewater treatment than aerobic ones [5-9].

The successful wastewater treatment required careful monitoring of the process parameters, and various methods were currently used to intensify and optimize these processes. These methods include the following.

Accounting qualitative properties of the treated wastewater allowed to predict mode of the biodegradation (carbohydrates and proteins was rapidly degraded and modified into substrates for methanogens) and biogas production (the biodegradability of lipids was lower, but provide the high yield and quality of biogas) [10].

A good result was obtained by the formation of microbial communities with high enzymatic activity, suitable substrate specificity, and temperature sensitivity [11-14]. The necessity of $\mathrm{pH}$ monitoring, selecting the optimal ratio of inoculate and substrate at the process start-up, sufficient mixing and small suspended matter particles size was shown [15-17]. The immobilization of the microbial biomass by granulation or biofilm formation [18-20] was very effective, but it was important to ensure the required surface quality of immobilizing device [21-22]. The various inhibitory effects elimination also significantly increased the efficiency of the methanogenic process [23, 24]. In addition, co-digestion of food waste with animal manure, sewage sludge and green waste was proposed [15].

It as shown that the temperature significantly affected the process of anaerobic wastewater treatment under mesophilic $\left(37^{\circ} \mathrm{C}\right)$ and thermophilic $\left(55^{\circ} \mathrm{C}\right)$ conditions [25-27]. A study of the combined system of up-flow anaerobic sludge blanket (UASB) and membrane bioreactor (MBR) showed a high resistance to changes in the organic loading rate (up to $4.85 \mathrm{~kg} \mathrm{COD} \mathrm{m}^{-3} \cdot$ day $^{-1}$ ) and temperature $\left(17-25^{\circ} \mathrm{C}\right)$, the degree of removal of COD reached $99 \%$ during the stable operation mode. The specific yield of biogas reached $1501 \cdot \mathrm{kg}^{-1}$ COD consumed with an average methane content of $73 \%$ vol.,

\footnotetext{
*Corresponding author: hrustik@yandex.ru
} 

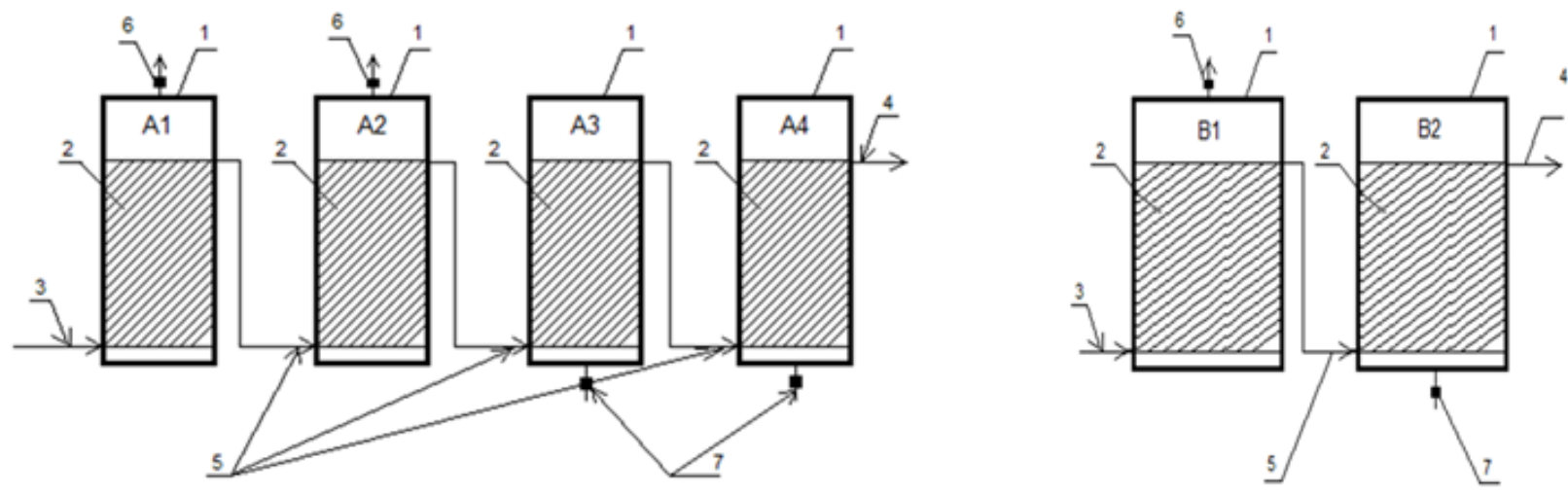

Fig. 1. Principle schemes of bioreactors connection: 1 - bioreactors, 2 - inert material with immobilized biomass, 3 - wastewater inlet to the first bioreactor, 4 - outlet of the purified water, 5 - overflow pipelines, 6 - biogas outflow, 7 - air for the aerobic stage aeration.

the specific yield of biomass ranged from 0.07 to $0.13 \mathrm{~g}$ of biomass (volatile suspended substances) from $1 \mathrm{~g}$ of COD consumed [28].

In order to degrade biopolymers, pre-treatment of wastewater was performed by chemical (acid, alkaline hydrolysis, oxidants) or biological methods (the enzymatic hydrolysis) [29-32]. Subsequently, two- and three-phase anaerobic systems for dairy wastewater treatment were proposed, in which the first-phase bioreactor was designed for polymer hydrolysis and fatty acid synthesis (acidogenesis) and provided the substrate for the second phase (methanogenesis) bioreactor. This scheme was effective for wastewater treatment with high content of suspended substances, for example, food industry and agriculture [33, 34]. The results of the systems with pre-acidification were widely presented in literature [35-40], while the chemical composition of the resulting metabolites was compared at different $\mathrm{pH}$ values [16], process parameters at different flow rates and retention time, and their effectiveness was compared at different temperatures [41].

A number of studies investigated the hardware design of the process of anaerobic treatment of dairy wastewater, namely, the advantages and disadvantages of various reactor designs [13, 18, 19, 29]. Anaerobic bio filter was suitable for the treatment of milk wastewater containing low content of suspended solids, and at the hydraulic retention time (HRT) of 4 days, the bioreactor provided destruction of organic matter 78-92\% [42]. An anaerobic up-flow bio filter also showed the efficiency of COD removal on average $80 \%$ during dairy wastewater treatment at organic loading rate $\mathrm{L}$ up to 21 $\mathrm{kg} \mathrm{COD} \cdot \mathrm{m}^{-3} \cdot \mathrm{day}^{-1}$ [43]. An industrial anaerobic bio filter for raw milk wastewater treatment at the $\mathrm{L}$ up to $6 \mathrm{~kg}$ $\mathrm{COD} \cdot \mathrm{m}^{-3} \cdot \mathrm{day}^{-1}$ showed an efficiency of COD removal of about $90 \%$, while fat was also effectively decomposed [44].

The use of combined (anaerobic-aerobic) methods of wastewater treatment with stages separation into phases was considered optimal $[8,38]$. However, to obtain the desired effect, it was necessary to ensure the correct ratio of phases volumes due to the difference in the growth rate of the consortium bacteria. The solution of this problem required preliminary laboratory simulation of the treatment process, followed by its mathematical optimization either for the total volume of the bioreactor, or for the energy efficiency of the process [4-5].

In this regard, the paper objectives are as follows:

1. Study of the influence of the wastewater dilution rate $\mathrm{D}$ and organic loading rate $\mathrm{L}$ on the parameters of the dairy wastewater anaerobic treatment process;

2. Influence of the anaerobic phases spatial separation on the treatment efficiency;

3. Correlation analysis of the L, D and organic consumption rate $\mathrm{P}$ on the treatment efficiency.

\section{Materials and methods}

In simulation of the dairy wastewater treatment wastewater from the milk-processing enterprise was used. Laboratory installations A and B included anaerobic and aerobic stages with suspended and immobilized biomass. Installation A with the separation of stages into two phases consisted of four bioreactors $\mathrm{A}_{1}, \mathrm{~A}_{2}$ (anaerobic stage), $\mathrm{A}_{3}, \mathrm{~A}_{4}$ (aerobic stage). Installation $\mathrm{B}$ without dividing into phases included bioreactors B1 (anaerobic stage) and B2 (aerobic stage). Laboratory installations design and pipelines connecting are shown in Figure 1. Characteristics of laboratory bioreactors are presented at Table 1 .

Table 1. Volumes of bioreactors.

\begin{tabular}{|c|c|c|c|}
\hline $\begin{array}{c}\text { Installation } \\
\text { name }\end{array}$ & $\begin{array}{c}\text { Bioreactors } \\
\text { name }\end{array}$ & $\begin{array}{c}\text { Unit of } \\
\text { measure }\end{array}$ & $\begin{array}{c}\text { Numerical } \\
\text { value }\end{array}$ \\
\hline $\mathrm{A}$ & $\mathrm{A}_{1}$ & $\mathrm{dm}^{3}$ & 0.75 \\
\hline & $\mathrm{A}_{2}$ & - "- & 1.5 \\
\hline & $\mathrm{A}_{3}$ & - "- & 0.56 \\
\hline & $\mathrm{A}_{4}$ & - "- & 1.76 \\
\hline $\mathrm{B}$ & $\mathrm{B}_{1}$ & - "- & 1.02 \\
\hline & $\mathrm{B}_{2}$ & $-"-$ & 2.64 \\
\hline
\end{tabular}

The operating parameters were varied by changing the incoming wastewater volumetric flow rate $G$ and organic matter content $\mathrm{S}_{0}$, which caused corresponding changes in the dilution rate $\mathrm{D}$ and organic loading rate $\mathrm{L}$. 
Table 2. Characteristics of the investigated modes.

\begin{tabular}{|c|c|c|c|c|l|}
\hline Mode & Installation & Bioreactors & $\mathrm{G}, 10^{-6} \cdot \mathrm{m}^{-3} \cdot \mathrm{h}^{-1}$ & $\mathrm{~S}_{0}, \mathrm{~g}$ COD $\cdot \mathrm{dm}^{-3}$ & \multicolumn{1}{|c|}{ Short description } \\
\hline 1 & $\mathrm{~A}$ & $\mathrm{~A}_{1}-\mathrm{A}_{4}$ & $78.0 \pm 8.0$ & $3.8 \pm 0.8$ & Phase separation, low D \\
\hline 2 & & $\mathrm{~A}_{1}-\mathrm{A}_{4}$ & $112.0 \pm 10.1$ & $3.8 \pm 1.0$ & Phase separation, medium D \\
\hline 3 & & $\mathrm{~A}_{1}-\mathrm{A}_{4}$ & $149.0 \pm 15.1$ & $3.8 \pm 0.9$ & Phase separation, high D \\
\hline 4 & & $\mathrm{~A}_{1}-\mathrm{A}_{4}$ & $78.0 \pm 8.0$ & $4.2 \pm 1.0$ & Phase separation, low D, medium S \\
\hline 5 & & $\mathrm{~A}_{1}-\mathrm{A}_{4}$ & $78.0 \pm 8.0$ & $6.8 \pm 1.6$ & Phase separation, low D, double S \\
\hline 6 & $\mathrm{~B}$ & $\mathrm{~B}_{1}-\mathrm{B}_{2}$ & $78.0 \pm 8.0$ & $3.7 \pm 1.0$ & Without phase separation, low D \\
\hline 7 & & $\mathrm{~B}_{1}-\mathrm{B}_{2}$ & $149.0 \pm 15.1$ & $3.5 \pm 0.9$ & Without phase separation, high D \\
\hline
\end{tabular}

A number of process modes were implemented and their main parameters are presented in Table 2.

In the described modes continuous anaerobic treatment was simulated to reach a steady-state, which took on average about 12-16 days, at temperatures from 22.0 to $26.0^{\circ} \mathrm{C}$.

The following measured characteristics were used for the calculation of the technological parameters: the wastewater volumetric flow rate $\mathrm{G}, \mathrm{m}^{3} \cdot \mathrm{h}^{-1}$, was measured by the volumetric method; the content of organic matter $\mathrm{S}, \mathrm{kg} \mathrm{COD} \cdot \mathrm{m}^{-3}$, at the inlet and outlet of all phases bioreactors $\mathrm{A}_{1}-\mathrm{A}_{4}$ and $\mathrm{B}_{1}-\mathrm{B}_{2}$ was determined by the standard dichromate method.

Using the measurements, determined the estimated technological parameters for the following formulas 1-4: dilution rate $\mathrm{D}$, day ${ }^{-1}$, organic loading rate $\mathrm{L}, \mathrm{kg} \mathrm{COD} \cdot \mathrm{m}^{-}$ ${ }^{3} \cdot$ day $^{-1}$, organic consumption rate, $\mathrm{P}, \mathrm{kg} \mathrm{COD} \cdot \mathrm{m}^{-3} \cdot \mathrm{day}^{-1}$, treatment efficiency $\mathrm{E}, \%$, in bioreactor of each phase and in the installation as a whole $[17,22]$ :

$$
D=\frac{G}{V_{\mathrm{p}}}
$$

where $\mathrm{G}$ is wastewater volumetric flow rate, $\mathrm{dm}^{3} \cdot \mathrm{day}^{-1}$, $\mathrm{V}_{\mathrm{P}}$ are the bioreactors volumes on each phase, $\mathrm{dm}^{3}$,

$$
L=S_{\text {in }} \cdot D
$$

where $S_{\text {in }}$ is organic matter content in the incoming wastewater, $\mathrm{kg} \mathrm{COD} \cdot \mathrm{m}^{-3}$.

$$
P=\left(S_{\text {in }}-S_{\text {out }}\right) \cdot D
$$

where $S_{\text {out }}$ is organic matter content in the outgoing wastewater, $\mathrm{kg} \mathrm{COD} \cdot \mathrm{m}^{-3}$, as well as in the purified water at the outlet of the bioreactors of each phases.

$$
E=\frac{S_{\text {in }}-S_{\text {out }}}{S_{\text {in }}} \cdot 100 \%
$$

\section{Results and discussion}

\subsection{The effect of hydraulic and organic loads on the performance of the process}

In this section we carried out study to complete task 1 , i.e. to determine the influence of hydraulic and organic loads on the performance of the process. The hydraulic and organic loads were characterized by the dilution rate $\mathrm{D}$ and the organic loading rate $\mathrm{L}$, respectively. The

\begin{tabular}{|c|c|c|}
\hline Mode & D, day $^{-1}$ & $\mathrm{~L}, \mathrm{~kg} \mathrm{COD} \cdot \mathrm{m}^{-3} \cdot \mathrm{day}^{-1}$ \\
\hline 1 & $0.4 \pm 0.2$ & $1.4 \pm 0.2$ \\
\hline 2 & $0.6 \pm 0.1$ & $2.0 \pm 0.3$ \\
\hline 3 & $0.8 \pm 0.1$ & $3.0 \pm 0.4$ \\
\hline 4 & $0.4 \pm 0.1$ & $1.7 \pm 0.3$ \\
\hline 5 & $0.4 \pm 0.1$ & $2.8 \pm 0.4$ \\
\hline 6 & $0.4 \pm 0.1$ & $0.9 \pm 0.1$ \\
\hline 7 & $0.8 \pm 0.1$ & $2.8 \pm 0.4$ \\
\hline
\end{tabular}
results of calculations are presented in Table 3 .

Table 3. Hydraulic and organic load over the entire installation.

The efficiency indicator - treatment efficiency E, \%, was calculated according to formula 4, taking into account organic matter content at the inlet and outlet of each bioreactor. These measured values are presented in Table 4. D, L and E values calculated according to equations 1, 2, 4 are shown in Tables $5-7$.

The influence of studied parameters could be understood by varying them with simultaneous stabilization of all other parameters. For this purpose, we compared the process indicators in modes 1, 2, 3

\begin{tabular}{|c|c|c|c|c|c|c|c|}
\hline Mode & $A_{1}$ in & $\mathrm{A}_{1}$ out & $\mathrm{A}_{2}$ out & $\mathrm{A}_{3}$ out & $\mathrm{A}_{4}$ out & $\mathrm{B}_{1}$ out & $\mathrm{B}_{2}$ out \\
\hline 1 & 3.97 & 2.24 & 0.27 & 0.10 & 0.05 & & \\
\hline 2 & 3.90 & 2.67 & 0.79 & 0.08 & 0.03 & & \\
\hline 3 & 3.84 & 2.69 & 0.49 & 0.11 & 0.05 & & \\
\hline 4 & 4.19 & 2.30 & 0.39 & 0.07 & 0.04 & & \\
\hline 5 & 6.81 & 3.12 & 0.42 & 0.09 & 0.01 & & \\
\hline 6 & 3.37 & & & & & 1.65 & 0.85 \\
\hline 7 & 3.48 & & & & & 1.90 & 0.64 \\
\hline
\end{tabular}
(varying hydraulic load), then modes 1, 4, 5 (varying organic load).

Table 4. Organic matter content $\mathrm{S}, \mathrm{kg} C O D \cdot \mathrm{m}^{-3}$, at the inlet and outlet of bioreactors $\mathrm{A}_{1}-\mathrm{A}_{4}$ and $\mathrm{B}_{1}-\mathrm{B}_{2}$. 
Table 5. Dilution rate D, day ${ }^{-1}$.

\begin{tabular}{|c|c|c|c|c|c|c|}
\hline Mode & $\mathbf{A}_{1}$ & $\mathbf{A}_{2}$ & $\mathbf{A}_{3}$ & $\mathbf{A}_{4}$ & $\mathbf{B}_{1}$ & $\mathbf{B}_{2}$ \\
\hline 1 & 2.50 & 1.25 & 3.35 & 1.06 & & \\
\hline 2 & 3.58 & 1.79 & 4.80 & 1.53 & & \\
\hline 3 & 4.77 & 2.38 & 6.39 & 2.03 & & \\
\hline 4 & 2.50 & 1.25 & 3.35 & 1.06 & & \\
\hline 5 & 2.50 & 1.25 & 3.35 & 1.06 & & \\
\hline 6 & & & & & 1.84 & 0.71 \\
\hline 7 & & & & & 3.51 & 1.35 \\
\hline
\end{tabular}

Table 6. Organic loading rate $\mathrm{L}, \mathrm{kg} C O D \cdot \mathrm{m}^{-3} \cdot$ day $^{-1}$.

\begin{tabular}{|c|c|c|c|c|c|c|}
\hline Mode & $\mathrm{A}_{1}$ & $\mathrm{~A}_{2}$ & $\mathrm{~A}_{3}$ & $\mathrm{~A}_{4}$ & $\mathrm{~B}_{1}$ & $\mathrm{~B}_{2}$ \\
\hline 1 & 9.90 & 2.80 & 0.89 & 0.10 & & \\
\hline 2 & 13.98 & 4.72 & 3.77 & 0.12 & & \\
\hline 3 & 18.30 & 6.42 & 3.15 & 0.22 & & \\
\hline 4 & 10.46 & 2.89 & 1.29 & 0.08 & & \\
\hline 5 & 17.01 & 3.90 & 1.41 & 0.09 & & \\
\hline 6 & & & & & 6.19 & 1.17 \\
\hline 7 & & & & & 12.20 & 2.57 \\
\hline
\end{tabular}

Table 7. Treatment efficiency E ( $\%$ of the current phase).

\begin{tabular}{|c|c|c|c|c|c|c|c|}
\hline Mode & $\mathrm{A}_{1}$ & $\mathrm{~A}_{2}$ & $\mathrm{~A}_{3}$ & $\mathrm{~A}_{4}$ & $\mathrm{~B}_{1}$ & $\mathrm{~B}_{2}$ & Total \\
\hline 1 & 44.4 & 85.8 & 60.6 & 45.0 & & & 98.7 \\
\hline 2 & 32.7 & 66.8 & 90.1 & 65.2 & & & 99.3 \\
\hline 3 & 29.7 & 84.1 & 55.5 & 57.5 & & & 98.7 \\
\hline 4 & 44.8 & 83.6 & 81.5 & 55.7 & & & 99.2 \\
\hline 5 & 54.2 & 86.5 & 79.6 & 82.5 & & & 99.8 \\
\hline 6 & & & & & 45.5 & 47.7 & 73.9 \\
\hline 7 & & & & & 44.1 & 64.8 & 81.4 \\
\hline
\end{tabular}

The influence of the dilution rate $\mathrm{D}$ on the treatment efficiency $\mathrm{E}$ is shown in Figure 2. According to the presented data, with an increase in dilution rate $\mathrm{D}$ from 0.4 to 0.6 and further to 0.8 (modes $1,2,3$ ), there were practically no changes in the overall efficiency of the installations, amounting to 98.7-99.3\%. However, the efficiency of the anaerobic phases decreased with D increase in the studied range, so at the 1st anaerobic phase $A_{1} E$ decreased from 44.4 to $29.7 \%$, and at the second anaerobic phase $\mathrm{A}_{2}$ - it was slightly reduced from 85.8 to $66.8-84.1 \%$. Under these conditions, duty of organic destruction was shifted to the last aerobic bioreactors $\mathrm{A}_{3}$ and $\mathrm{A}_{4}$.

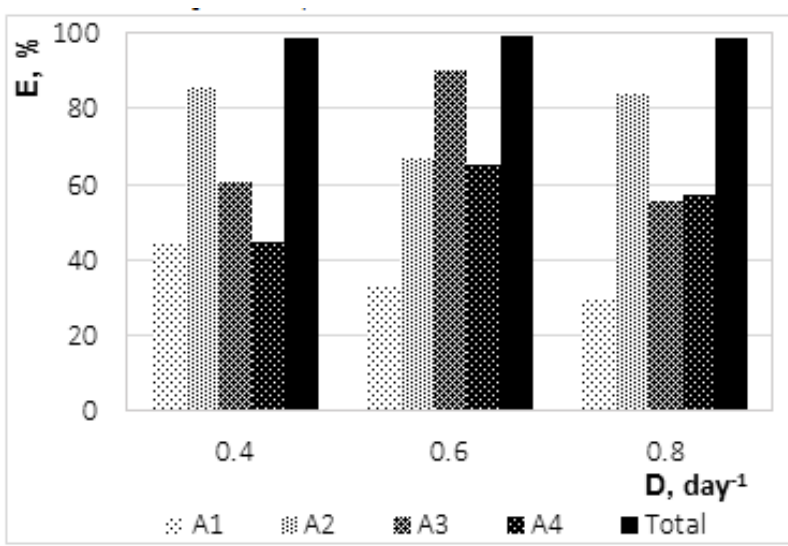

Fig. 2. Influence of the dilution rate D on treatment efficiency E.
The influence of the organic loading rate $\mathrm{L}$ on the treatment efficiency E is shown in Figure 3. Considering the impact of $\mathrm{L}$ on the treatment efficiency $\mathrm{E}$ at the same dilution rate $\mathrm{D}$ (modes $1,4,5$ ), it can be noted that at the first phase $A_{1} E$ increased from 44.4 to $54.2 \%$ with a constant efficiency of the second anaerobic stage $A_{2}$ at $85.8-86.2 \%$. The treatment efficiency at the aerobic phases also increased, from 60.6 to $81.5-79.5 \%$ at the $\mathrm{A}_{3}$ and from $45 \%$ to $85.2 \%$ at the last bioreactor $A_{4}$. The efficiency of the installation as a whole, with varying organic load, practically did not change and amounted to 98.7-99.8\%.

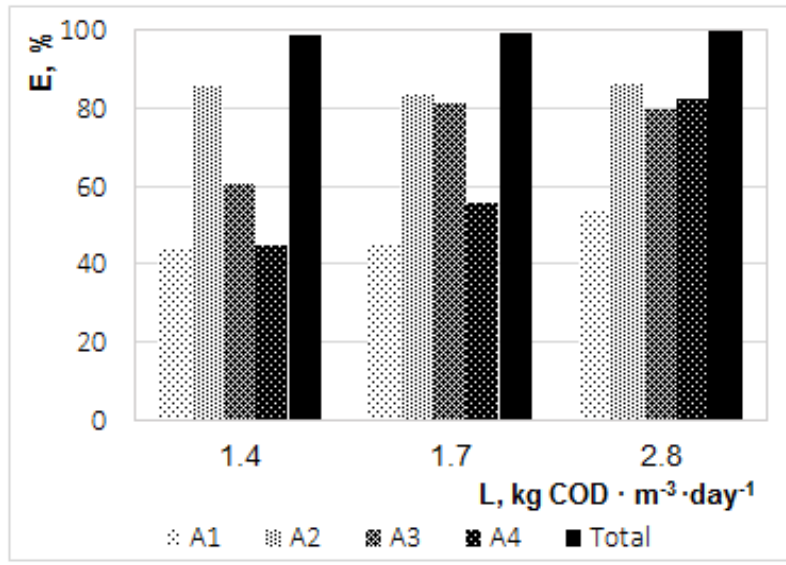

Fig. 3. Influence of the organic loading rate $\mathrm{L}$ on treatment efficiency E. 
Table 8. Treatment efficiency E ( $\%$ of the current phase).

\begin{tabular}{|c|c|c|c|c|c|c|c|}
\hline Mode & $\mathrm{A}_{1}$ & $\mathrm{~A}_{2}$ & $\mathrm{~A}_{3}$ & $\mathrm{~A}_{4}$ & $\mathrm{~B}_{1}$ & $\mathrm{~B}_{2}$ & Overall \\
\hline 1 & 44.4 & 85.8 & 60.6 & 45.0 & & & 98.7 \\
\hline 3 & 29.7 & 84.1 & 55.5 & 57.5 & & & 98.7 \\
\hline 6 & & & & & 45.5 & 47.7 & 73.9 \\
\hline 7 & & & & & 44.1 & 64.8 & 81.4 \\
\hline
\end{tabular}

\subsection{Influence of spatial separation of stages into phases}

In section 3.2 we conducted research in accordance with second task - influence of phases spatial separation on the treatment efficiency. This research involved comparing process indicators at different conditions with separation of treatment stages into phases and without separation (modes 1 and 3 were compared with modes 6 and 7, respectively, since they had equivalent characteristics including $\mathrm{S}$ and $\mathrm{G}$ ). According to the data provided in Table 8, the wastewater treatment without phase spatial separation had lower treatment efficiency both in the anaerobic and aerobic stages as well as a whole (73.9-81.4 versus 98.7\%), that confirmed the fact of process efficiency increase with the spatial separation of methanogenic microbial biocenoses.

\subsection{Correlation analysis between organic loading rate $\mathrm{L}$, organic consumption rate $\mathrm{P}$ and dilution rate $D$}

To complete task 3 we performed a correlation analysis between key technology parameters L, P, D and
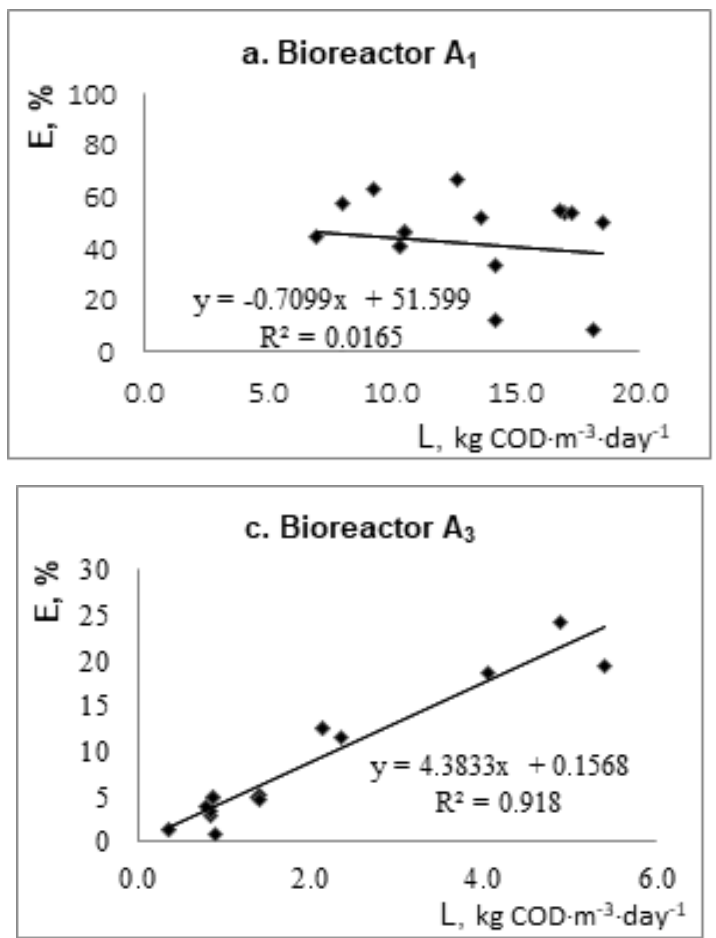

treatment efficiency E, followed by parametric identification of these dependencies.

Based on organic content analyses at the inlet and outlet of each phase bioreactors according to the previously indicated formulas 2- 4 the L, P and E values were calculated. From these experimental numerical values of $\mathrm{E}$ in relation to the corresponding $\mathrm{L}$ values, it was possible to determine the parameters of the correlation dependence $E=f(L)$ shown in Figure 4.

When analysing the correlation of these parameters, it was found that if there was no relationship between the effectiveness of cleaning and the organic loading rate at stage 1 of treatment (Fig. 4.a), as evidenced by a low value of the correlation coefficient equal to 0.0165 , then at subsequent stages installation, there were correlations between the parameters under consideration (Fig. 4 b, c, d) with high values of the correlation coefficients. The dependence coefficients and correlation coefficients are shown in Table 9.

A similar analysis was carried out for the specific rate of organic consumption rate $\mathrm{P}, \mathrm{kg}$ COD. $\mathrm{m}^{-3}$. $\mathrm{day}^{-1}$, at separate stages. Linear dependence quotients of organic consumption rate versus organic loading rate $L$ on the installation are also presented in Table 9.

The revealed correlations could be used for
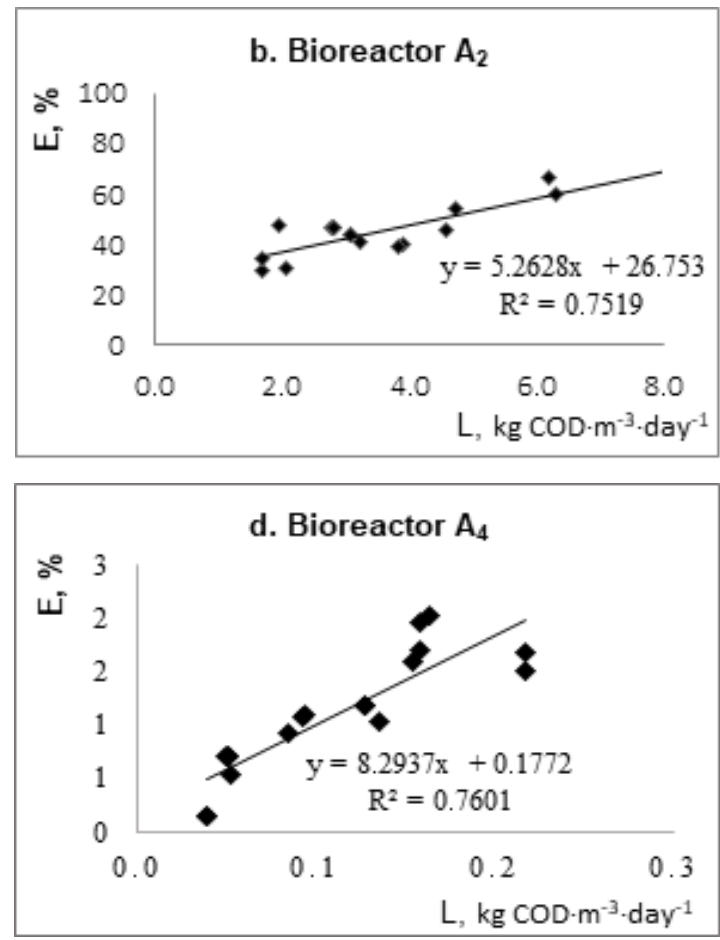

Fig. 4. Correlation of treatment efficiency $\mathrm{E}$ and organic loading rate $\mathrm{L}$. 
Table 9. Correlations $E=f(L)$ and $P=f(L)$.

\begin{tabular}{|c|c|c|c|c|}
\hline \multirow{2}{*}{ Phases } & Function according to & Credibility & Function according to & Credibility \\
\cline { 2 - 5 } & \multicolumn{2}{|c|}{$\mathbf{E}=\mathbf{f}(\mathbf{L})$} & \multicolumn{2}{c|}{$\mathbf{P}=\mathbf{f}(\mathbf{L})$} \\
\hline $\mathrm{A}_{1}$ & $\mathrm{E}=-0.7099 \cdot \mathrm{L}+51.599$ & 0.0165 & $\mathrm{P}=0.3575 \cdot \mathrm{L}+0.7806$ & 0.1849 \\
\hline $\mathrm{A}_{2}$ & $\mathrm{E}=5.2628 \cdot \mathrm{L}+26.753$ & 0.7519 & $\mathrm{P}=0.7558 \cdot \mathrm{L}+0.2452$ & 0.9713 \\
\hline $\mathrm{A}_{3}$ & $\mathrm{E}=4.3833 \cdot \mathrm{L}+0.1568$ & 0.9180 & $\mathrm{P}=0.9354 \cdot \mathrm{L}-0.2376$ & 0.9879 \\
\hline $\mathrm{A}_{4}$ & $\mathrm{E}=8.2937 \cdot \mathrm{L}+0.1772$ & 0.7601 & $\mathrm{P}=0.581 \cdot \mathrm{L}+0.0001$ & 0.9515 \\
\hline
\end{tabular}

mathematical simulation and optimization of the process of anaerobic-aerobic biological wastewater treatment of milk processing enterprises.

\section{Conclusions}

1. Obtained result showed that an increase of dilution rate $D$ reduced the organic matter treatment efficiency $E$ at the anaerobic stage, which was compensated by the activation of the aerobic stage. Increasing the organic loading rate $\mathrm{L}$ improves the state of the treatment process at the anaerobic stage.

2. Studies showed that spatial separation of anaerobic phases increased the efficiency of wastewater treatment compared to non-separation in both the anaerobic and aerobic stages, as well as in general.

3 . The correlation analysis of the organic loading rate $\mathrm{L}$, organic consumption rate $\mathrm{P}$ and dilution rate $\mathrm{D}$ on the cleaning efficiency $\mathrm{E}$ allowed to obtain the equations could be used for mathematical optimization of the process.

\section{References}

1. A. Kolev Slavov, Food Technol. Biotechnol., 55, 14-28 (2017)

2. K. Zhao, Y.W. Wu, S. Young, X.J. Chen., J. Environ. Informatics Lett., 4, 22-31 (2020)

3. C. Tocchi, E. Federici, S. Scargetta, A. D’Annibale, M. Petruccioli., Proc. Biochem., 48, 941-944 (2013)

4. Z. Ritambhara, V. Sivakumar, K.P. Himanshu, K. Munish., Biol. Treatm. of Indust. Waste Wat. and their Recycl. for a Sust. Futur., Springer Singapore, 91-115 (2019)

5. R. Mendez, R. Blazquez, F. Lorenzo, J.M. Lema, Water Sci. Technol., 21, 1857-1860 (1989)

6. H.N. Gavala, I.V. Skiadas, N.A. Bozinis, G. Lyberatos, Water Sci. Technol., 34, 67-75 (1996)

7. K.V. Rajeshwari, M. Balakrishnan, A. Kansal, K. Lata, V.V.N. Kishore, Renew. Sustain. energy Rev., 4, 135-156 (2000)

8. B. Demirel, O. Yenigun, T.T. Onay, Process Biochem., 40, 2583-2595 (2005)

9. R. Khabibullin, A. Petrov, I. Knyazev, Bulletin of the Kazan Technol. Univer., 19, 127-129 (2012)

10. C. Morales-Polo, M. del Mar Cledera-Castro, B. Yolanda Moratilla Soria, Appl. Sci., 8, 1-35 (2018)

11. N.I. Krylova, A.I. Obraztsova, R.E. Khabibullin, K.S. Laurinavicius, R.P. Naumova, V.K.
Akimenko, Prikladnaya biokhimiya i mikrobiologiya, 30 (1) (1994)

12. S. Goblos, P. Portoro, D. Bordas, M. Kalman, I. Kiss, Renew. Energy, 33 (5), 960-965 (2008)

13. M.A. Gladchenko, V.I. Sklyar, S.V. Kalyuzhnyj, Production of ethanol and distilled beverages, 1 (2001)

14. D.I. Masse, L. Masse, Bioresour. Technol., 76, 2, 91-98 (2001)

15. D.Y.C. Leung, J. Wang, Int. J. Green Energy, 13 (2), 119-131 (2016)

16. H.G. Yu, H.H. Fang, Water Sci. Technol., 45 (10), 201-206 (2002)

17. R.E. Speece, a description of several installations, Envlron. Sci. Technol., 17 (9), 416-427 (1983)

18. S.V. Kalyuzhnyj, A.G. Puzankov, S.D. Varfolomeev, Results in science and engineering, Biotechnology, 21 (1988)

19. S.V. Kalyuzhnyj, D.A. Danilovich, A.N. Nozhevnikova, Results in science and engineering, Biotechnology, 29 (1991)

20. T. Maekawa, C.M. Liao, X.D. Feng, Water Res., 29 (12), 2643-2650 (1995)

21. A. Ugurlu, C.F. Forster, Trans. Inst. Chem. Eng., 69, 37-42 (1991)

22. A. Ugurlu, C.F. Forster, Bioresour. Technol., 39 (1), 23-30 (1992)

23. P. Wang, H. Wang, Y. Qiu, L. Ren, B. Jiang, Bioresour. Technol., 248, 29-36 (2018)

24. P. Chatterjee, L. Lahtinen, M. Kokko, J. Rintala, Water Res., 143, 209-217 (2018)

25. W.T. Liu, O.C. Chan, H.H.P. Fang, Water Res., 36 (13), 3203-3210 (2002)

26. H.Q. Yu, H.H.P. Fang, Trans. Am. Soc. Agric. Eng., 44 (5), 1357-1361 (2001)

27. H.Q. $\mathrm{Yu}$, H.H.P. Fang, G.W. Gu, Process Biochem., 38 (3), 447-454 (2002)

28. D. Buntner, A. Sánchez, J.M. Garrido, Chem. Eng. J., 230, 475-481 (2013)

29. C.F. Chu, Y.Y. Li, K.Q. Xu, Y. Ebie, Y. Inamori, H.N. Kong, Int. J. Hydrogen Energy, 33 (18), 4739-4746 (2008)

30. S. Kalyuzhnyi, A. Veeken, B. Hamelers, Water Sci. Technol., 41 (3), 43-50 (2000)

31. J. Kim., C. Park, T. Kim, M. Lee, S. Kim, S. Kim, J. Lee, J. Biosci. Bioeng., 95 (3), 271-275 (2003)

32. E. Salminen, J. Rintala, Bioresour. Technol., 83 (1), 13-26 (2002)

33. L. Guerrero, F. Omil, R. Mendez, J.M. Lema, Water Res., 33 (15), 3281-3290 (1999)

34. B. Demirel, O. Yenigun, J. Chem. Technol. Biotechnol., 77 (7), 743-755 (2002) 
35. I.E. Alexiou, G.K. Anderson, L.M. Evison, Water Sci. Technol., 29 (9), 199-204 (1994)

36. Y. Yu, C.L. Hansen, S. Hwang, Biotechnol. Bioeng., 78 (2), 147-156 (2002)

37. B. Demirel, O. Yenigun, J. Chem. Technol. Biotechnol., 79 (7), 755-760 (2004)

38. H.Q. Yu, H.H.P. Fang, Water Res., 35 (15), $3697-$ 3705 (2001)

39. S. Pandey, S. Sarkar, J. Environ. Chem. Eng., 5 (2), 1575-1585 (2017)

40. R. Khabibullin, O. Ivanchenko, A. Petrov, R. Bhat, MATEC Web Conf., 245, 0-7 (2018)

41. H.Q. Yu, H.H.P. Fang, Water Sci. Technol., 46 (11-12), 153-157 (2002)

42. T. Viraraghavan, S.R. Kikkeri, Can. Agric. Eng., 33 (1), 143-149 (1991)

43. O. Ince, B. Kasapgil Ince, T. Donnelly, Water Sci. Technol., 41, 261-270 (2000)

44. F. Omil, J.M. Garrido, B. Arrojo, R. Méndez, Water Res., 37 (17), 4099-4108 (2003)

45. R. Khabibullin, T. Le Huong, O. Ivanchenko, A. Petrov, E3S Web Conf., 140, 3-6 (2019). 